\title{
ZASADNOŚĆ KONCEPCJI NOWEJ CYWILIZACJ ZAPROPONOWANEJ PRZEZ HERBERTA MARCUSEGO
}

\begin{abstract}
Streszczenie. Niniejszy artykuł dotyczy słuszności diagnozy dokonanej przez McKenziego, że w filozofii Herberta Marcusego jest mowa o tym, co dzisiaj nazywa się performansem organizacyjnym. Ale głównym celem niniejszych rozważań jest znalezienie odpowiedzi na pytanie, czy propozycja stworzenia nowej cywilizacji przedstawiona przez Marcusego oraz próba teoretycznego pogodzenia zasady przyjemności z zasadą rzeczywistości jest możliwa. Marcuse przedstawia wizję nowego społeczeństwa jako alternatywę dla dotychczasowego społeczeństwa przemysłowego. Łączy on perspektywę Marksowską z Freudowską, a to dlatego, że uznał on, iż dopiero połączenie teorii sił wytwórczych i rozważań psychoanalitycznych pomoże ustalić niezbędne warunki do powstania nowej, nierepresywnej rzeczywistości. Nawoływał do stworzenia projektu nowej zasady rzeczywistości, która nie wykluczałaby zasady przyjemności. Wydaje się jednak, że nie zauważył on faktu, iż siły mutacyjne niemalże niepostrzeżenie przechodzą w siły normatywne. To, czego spodziewał się Marcuse, z jednej strony spełniło się, z drugiej zaś stworzyło szereg wątpliwości, jak i niedogodności praktycznych, których nie przewidział.
\end{abstract}

Słowa kluczowe: performans organizacyjny, zasada wydajności, zasada rzeczywistości, nowa wrażliwość, represja, Eros, normatywność

1. Wstęp. 2. Performans organizacyjny a zasada wydajności. 3. Zastosowanie teorii krytycznej do opisu rzeczywistości społeczeństwa przemysłowego. 4. Diagnoza cywilizacji opartej o zasadę wydajności i propozycja nowej zasady rzeczywistości. 5. Wnioski.

\section{WSTĘP}

Celem niniejszego artykułu jest zbadanie, czy koncepcja stworzenia nowej cywilizacji przez Herberta Marcusego ${ }^{1}$ jest poprawna.

1 Herbert Marcuse (1898-1979) - niemiecki filozof, przedstawiciel szkoły frankfurckiej, neomarksista; badacz przemysłowego społeczeństwa konsumpcyjnego, racjonalności technologicznej i zrepresjonowanej kultury. 
Odwołuje się on do Freudowskiej interpretacji zasady rzeczywistości, jako przeciwnej do zasady przyjemności. Zasada rzeczywistości w odczuciu Marcusego została zredukowana do wymiaru ekonomicznego, do wydajnej pracy oraz jej efektywnej organizacji. Dlatego też wiąże zasadę rzeczywistości z zasadą wydajności, urzeczywistnioną w systemie kapitalistycznym.

Marcuse stara się zatem określić warunki, na których mogłaby powstać nowa, jakościowo odmienna, zasada rzeczywistości. Mialaby ona przyczyniać się do powstania nowego, lepszego społeczeństwa. Naszym celem jest więc zbadanie, na ile ta propozycja jest właściwa. Do poglądów Marcusego nawiązuje Jon McKenzie² ${ }^{2}$ twierdząc, że Marcuse jako pierwszy zauważył, że zasadą rzeczywistości stała się zasada wydajności. Co więcej, tę ostatnią zasadę amerykański badacz nazywa performansem organizacyjnym. Wiele wskazuje na to, że diagnoza McKenziego jest zasadniczo słuszna, ale nie do końca. Wydaje się bowiem, że Marcuse przedstawia propozycję odejścia od zasady wydajności i przejścia do nowej zasady rzeczywistości, która nie byłaby represywna. W swojej filozofii używa on określenia „nowa zasada rzeczywistości", ale prawdopodobnie chodzi mu o stworzenie nowej rzeczywistości, czy też zasady nowej rzeczywistości. Chcemy zatem zbadać, czy wizja Marcusego jest poprawna i możliwa do urzeczywistnienia. Tego typu przedsięwzięcie wydaje się zasadne, bowiem problematyka, którą poruszał niemiecki filozof, jest ciągle aktualna. Wiele też wskazuje na to, że zagadnienie, którego analizą zajmował się Marcuse, a później McKenzie, nie jest li tylko problemem szkoły frankfurckiej, której Marcuse był przedstawicielem. Czy zatem wizja Marcusego była realna i możliwa do spełnienia? Zastanowimy się zatem, na ile diagnoza McKenziego jest słuszna, tj. zbadamy, jak mają się do siebie zasada wydajności i performans

2 Jon McKenzie - współczesny, amerykański naukowiec; wykładowca Uniwersytetu Wisconsin-Madison, badacz teorii performansu, autor książki Performuj albo... Od dyscypliny do performansu, Kraków 2011. 
organizacyjny, a następnie przyjrzymy się, do jakich wniosków doszedł Marcuse stosując teorię krytyczną do opisu rzeczywistości społeczeństwa przemysłowego, by na koniec rozważyć proponowaną przez niego nową zasadę rzeczywistości. Dodać należy, by nie było wątpliwości, że słowo 'zasada' odpowiada łacińskiemu 'principium', a więc rozpatrywane będzie w sensie przyczynowym, w tym przypadku jako coś, co rządzi zachowaniem człowieka, a nie tylko jako zasada logicznego rozumowania.

\section{PERFORMANS ORGANIZACYJNY A ZASADA WYDAJNOŚCI}

Autor Performuj albo... Od dyscypliny do performansu słusznie zauważa, że zagadnienie performansu $\mathrm{w}$ ostatnim czasie zrobiło się bardzo popularne. Słowo performance występuje często w instrukcjach artykułów codziennego użytku, od sprzętów technicznych w naszych domach, przez szkolenia w zakresie zarządzania performatywnego po namysły nad performatywnością mowy codziennej. Performans tak głęboko przeniknął obecnie społeczeństwo amerykańskie, że stał się tajemniczą aurą otaczającą wszystko, co żyje, o czym pisał w Nierwczesnych rozważaniach ${ }^{3}$ Fryderyk Nietzsche, mówiąc, że bez tej tajemniczości życie ludzkie usycha, jałowieje i kostnieje. Jego zdaniem każdy człowiek, by mógł się rozwijać, potrzebuje ochronnej ułudy. Obserwując współczesną rzeczywistość trudno zakwestionować fakt, że performans stał się właśnie taką atmosferą otaczającą życie niemalże każdego człowieka.

Co więcej, performans poprzez swoją skuteczność rozwarstwia się w różnych kierunkach, pozostawia historyczne skutki w postaci słów i działań. Lektura dzieła McKenziego pokazuje coś, co inni komentatorzy i krytycy niemieckiego filozofa pominęli. Otóż McKenzie twierdzi, że ślady performansu, zwłaszcza w dziedzinie zarządzania, można znaleźć już w latach pięćdziesiątych XX w., na co zwrócił

3 Por. F. Nietzsche, Niewczesne rozważania, Kraków 1996, 134. 
uwagę właśnie Herbert Marcuse. Okazuje się, że już w roku 1955 pisał on w swoim sztandarowym dziele Eros i cywilizacja o zasadzie wydajności, która rządzi, jego zdaniem, postindustrialnym społeczeństwem, a którą to zasadę w książce Cztowiek jednowymiarowy ${ }^{5}$ nazywał racjonalnością technologiczną.

McKenzie stawia tezę, że Marcuse jako pierwszy dostrzegł analogię między krytykowaną przez siebie zasadą wydajności, obowiązującą w życiu gospodarczym, a performansem organizacyjnym, który wówczas zaczynał rozwijać się na dobre, a dzisiaj służy do zarządzania przedsiębiorstwem i nie tylko ${ }^{6}$. McKenziemu chodzi więc nie tylko o ukazanie roli performatyki w tradycyjnym tego słowa znaczeniu, odnoszącym się głównie do działań artystycznych, ale o sens, jaki to wyrażenie posiada dzisiaj, zwłaszcza gdy chodzi o jego odniesienie do przedsięwzięć stosowanych w gospodarce i ekonomii ${ }^{7}$. W ostatnich dziesięcioleciach nastąpił bowiem znaczący wzrost badań performatycznych, co doprowadziło do wyróżnienia trzech performansów: organizacyjnego, kulturowego i technicznego ${ }^{8}$.

4 H. Marcuse, Eros i cywilizacja, Warszawa 1998.

5 H. Marcuse, Człowiek jednowymiarowy, Warszawa 1991.

6 Pod koniec XX w. na obszarze filozofii zaczęło pojawiać się pojęcie perforamatyki. Jednakże termin ten ukuty został na pograniczu nauk humanistycznych i społecznych. McKenzie, powołując się na Oksfordzki Słownik Języka Angielskiego, wskazuje, że podobne użycia słowa 'performans' funkcjonowały już przez kilka ostatnich wieków. Jednakże w ostatnim półwieczu termin ten nabrał nowego znaczenia, radykalnie i nieoczekiwanie przekształcono go i rozbudowano. Na gruncie nauk społecznych i humanistycznych zaczęto używać pojęcia performansu w jego znaczeniu teatralnym, aby rozumieć rytuały społeczne i powszednie międzyludzkie relacje. Nieco później pojęcie performansu odnoszono do demonstracji politycznych i przedstawień artystycznych. Obecnie, jak to wskazuje McKenzie, wszystko jawi nam się jako performans: praca, zabawa, seks czy kontestacja, J. McKenzie, dz. cyt., 4, 16-17.

7 Jak wskazuje McKenzie, w dziedzinie finansów udziały, akcje, fundusze emerytalne, inwestycyjne oraz całe rynki analizuje się w kategoriach ich krótkoterminowego i długoterminowego „performansu”. Tamże, 16.

8 McKenzie dokonuje rozróżnienia na performanse: kulturowy, organizacyjny i technologiczny. W performansie kulturowym, performans uwydatnia się poprzez teatr, film czy telewizję, gdzie nieustannie uprawia się, omawia, recenzuje, reklamuje i konsumuje performanse 
Powstaje zatem pytanie, na ile diagnoza McKenziego jest trafna, zwłaszcza gdy chodzi o stwierdzenie, że już Marcuse, krytykując zasadę wydajności, miał na myśli to, co dzisiaj nazywa się z performansem organizacyjnym. Odpowiedź na to pytanie posłuży dalszym analizom, głównie zbadaniu tego, czy propozycja zastąpienia przez Marcusego zasady wydajności nową zasadą rzeczywistości, jak ją nazywa, dopuszczającą zasadę przyjemności w podejmowanych przez ludzi działaniach, jest właściwa.

\section{ZASTOSOWANIE TEORII KRYTYCZNEJ DO OPISU RZECZYWISTOŚCI SPOŁECZEŃSTWA PRZEMYSŁOWEGO}

Okazuje się, że Marcuse, jako członek szkoły frankfurckiej' ${ }^{9}$ tworzy teorię krytyczną, jak ją nazywa, i z jej perspektywy rozważa zasadę wydajności. Mimo że nie jest świadom tego, że opisywał coś, co dziś nazywa się performatyką, to dobrze zdiagnozował problem, który wpisuje się w szerszy krąg jego rozważań na temat społeczeństwa przemysłowego. Zwraca on uwagę na mocno konsumpcjonistyczny charakter opisywanego przez siebie społeczeństwa, czego krytyki podjął się głównie w Człowieku jednowymiarowym ${ }^{10}$. Marcusowska analiza performansu ważna jest z kilku powodów:

aktorów. W ciągu ostatniego półwiecza formy związane z przedstawieniem teatralnym przekształcono w narzędzia analityczne, uogólniono interdyscyplinarnie na różne pola badań i wykorzystano w najrozmaitszych kontekstach. W performansie organizacyjnym, performans ocenia się w kategoriach zysków, cen akcji i sprawności organizacyjnej. Performans technologiczny najpełniej uobecnia się $w$ dziedzinie przemysłu elektronicznego, informatycznego i telekomunikacyjnego. Tamże, 6, 9-10, 14.

9 Więcej na temat szkoły frankfurckiej czytelnik znajdzie w następujących opracowaniach: M. Jay, The Dialectical Imagination. A History of Frankfurt School and the Institute of Social Research. 1923-1950, Lo 1973; A. Szahaj, Teoria krytyczna szkoły frankfurckiej, Warszawa 2008; D. Held, Introduction to Critical Theory, Lo 1980; S. Buck-Morss, The Origin of Negative Dialectic. Theodor W. Adorno, Walter Benjamin and the Frankfurt-Institute, Hassocks 1978.

10 H. Marcuse, Człowiek jednowymiarowy, dz. cyt. 
- w siedem lat po przybyciu Marcusego do Ameryki, w roku 1941, rozpoznał on rolę performansu w mechanizmie konformizmu;

- w roku 1955 opracował pełną teorię zasady performansu, twierdząc, że II wojna światowa posłużyła Stanom Zjednoczonym za wydarzenie inicjacyjne performatywności ${ }^{11}$;

- zwrócił uwagę na pojawianie się i obecność nowych sił normujących ludzkie życie w sposób zniewalający;

- nikt nie dostrzegł tego wcześniej, bowiem powszechnie uważano, że performanse zmierzają jedynie do podważenia istniejących norm, a więc, że posiadają charakter mutacyjny i destrukcyjny;

- Marcusowskie obserwacje pokazują, że to, co badał, miało charakter normatywny;

- nie jest tak, że performatyka prowadzi do obalenia istniejących norm, w ich miejsce powstają nowe, o nowej treści;

- Marcuse pojmował władzę i dominację performansu, jego normatywny charakter głównie jako standaryzację społeczeństwa zgodnie z normami wydajności technicznej i ekonomicznej ${ }^{12}$.

We wczesnym ujęciu performansu przez Marcusego dostrzec można podstawę jego późniejszej teorii o „zasadzie performansu” oraz rozpoznać działanie performansu jako osobliwej formy władzy czy też formacji władzy jako sposobu dominacji. Niemniej niemiecki filozof zwraca uwagę, że zasada performansu przekracza racjonalność techniczną oraz alienację gospodarczą i sięga po społeczną organizację a poprzez wpływanie na kulturę masową, obejmuje także wypoczynek i życie prywatne, pracę i czas wolny. Co więcej, Marcuse sytuuje władze performansu w perspektywie historycznej i pokazuje, że racjonalność techniczna jest efektem i modyfikacją racjonalności krytycznej, zapoczątkowanej w czasach oświecenia. Zasada performansu

11 Por. J. McKenzie, dz. cyt., 205.

12 Por. P. Duchliński, A. Kobyliński, R. Moń, E. Podrez, O normatywności w etyce, WAM Ignatianum 2015, 202-204. 
dotyczy zatem każdej współczesnej subiektywności, jednocześnie rozciągając się na całe społeczeństwo i dominując nad wszystkimi formami życia: pracą, edukacją, rozrywką, seksualnością, a nawet nad buntem i protestem ${ }^{13}$.

McKenzie wskazuje, że Marcusowska teoria zasady performansu została opublikowana w 1955 roku. Stało się to dość dawno temu, co świadczy, że władzę performansu odczuwano w Stanach Zjednoczonych już w latach zimnej wojny, kiedy performatyka, technoperformans, i zarządzanie performatywne dopiero zaczynały się ujawniać. Twierdzi, że zagadnienie performatyki na gruncie filozofii Herberta Marcusego nie zostało od razu dostrzeżone. Spostrzeżenia Marcusego zostały pominięte. Sformułowana przez niemieckiego filozofa zasada performansu nie jest dziś należycie doceniana. Autor Performuj albo... przypuszcza, że taki stan rzeczy ma miejsce, ponieważ nieprzywoływanie pojęcia performansu czy zasady performansu w obrębie obowiązujących paradygmatów i dyskursów może być nakazem samej władzy performansu ${ }^{14}$. Nakazem o nieujawnianiu się, o niewyrażaniu wprost, zakazem mówienia metajęzykiem performansu.

McKenziemu chodzi o to, że Marcuse dostrzegł, że może mieć to związek ze zjawiskiem procesu reifikacji, w wyniku którego jednostka postrzega zjawiska i procesy społeczne, tak jakby były one pozaspołeczne, niezależne od działań społeczeństwa. Wprowadzona zasada traktowana jest na początku jako sztuczna i narzucona. Wydaje się ona wręcz bezzasadna. Jednak z czasem staje się na tyle trwałym elementem rzeczywistości społecznej, że nawet osoby, które brały udział w tworzeniu normy, zaczynają traktować ją jakby była prawem natury. McKenzie twierdzi, że normy nie są nam narzucane wprost, lecz przyjmujemy je bezwiednie, uważając, że są naszym wyborem. Ponadto pokazuje, że Marcusemu chodziło o zjawisko zacierania norm. W Erosie i cywilizacji Marcuse dostrzegł analogię

13 Por. J. McKenzie, dz. cyt., 205.

14 Por. tamże, 21. 
między performansem a psychoanalizą $\mathrm{w}$ procesie uwalniania się od istniejących norm, a jednocześnie tworzenia nowych. Pisał: „(...) zrównanie wolności ze szczęściem, wyklęte przez świadomość, jest popierane przez nieświadomość. Jej prawda, choć odpychana przez świadomość, wciąż jest w psychice żywa, zachowuje pamięć o poprzednich stadiach rozwoju jednostki, na których uzyskiwano pełne zaspokojenie. Przeszłość zgłasza wciąż roszczenia do przyszłości, a to właśnie rodzi pragnienie odtworzenia raju na podstawie osiągnięć cywilizacji”"15.

Czytając Erosa i cywilizację zauważamy, że Marcuse dokonał syntezy perspektyw Marksowskiej i Freudowskiej, mianowicie połączył teorię sił wytwórczych $\mathrm{z}$ teorią popędów proponując nową zasadę rzeczywistości. Warto zatem przyjrzeć się bliżej twórczości Marcusego, aby potwierdzić bądź obalić twierdzenie McKenziego. Marcuse pisze „(...) starając się naświetlić zakres i granice przeważającej represywności we współczesnej cywilizacji, będziemy musieli opisać ją w kategoriach konkretnej zasady rzeczywistości, która rządziła narodzinami i rozwojem tejże cywilizacji. Określamy ją jako zasadę wydajności (performansu), by podkreślić, że pod jej rząami społeczeństwo dzieli się na warstwy zgodnie z opartymi na rywalizacji dokonaniami jej członków. Nie jest to jedyna zasada rzeczywistości występująca w dziejach: inne modele organizacji społecznej nie tylko przeważały w prymitywnych kulturach, ale i dochowały się do czasów współczesnych" ${ }^{16}$. Tak więc zasada performansu jest zasadą rzeczywistości, podstawą dla tego, co później Marcuse nazwał społeczeństwem jednowymiarowym - czyli dla rozwiniętego społeczeństwa przemysłowego, w którym dominująca stratyfikacja społeczna opiera się na pracy. Niewolnicy rozwiniętej cywilizacji przemysłowej są wysublimowanymi niewolnikami, ponieważ niewolnictwo określa się nie przez posłuszeństwo, lub uciążliwość pracy, lecz przez nadany

15 H. Marcuse, Eros i cywilizacja, dz. cyt., 36.

16 Tamże, 59. 
człowiekowi status narzędzia i redukcję go do roli rzeczy. Istnienie jako narzędzie, jako rzecz, to czysta forma zniewolenia ${ }^{17}$.

Analiza dzieł Marcusego pokazuje, że:

- łączy on teorię sił wytwórczych z teorią popędów w celu zdefiniowania i wykazania historycznej zasady rzeczywistości w postaci reżimu represywnych sił, które uważa za kluczowe dla powojennej cywilizacji przemysłowej;

- utrzymuje on, że opisywana tam zasada wydajności kieruje społeczeństwem podzielonym na warstwy, zgodnie z opartymi na rywalizacji społecznymi dokonaniami jej członków, które z czystym sumieniem możemy postrzegać jako performance;

- „Marcuse - jak zauważają autorzy O normatywności w etyce twierdzi1, że nie trzeba już dokonywać zorganizowanej dominacji, bo ona już jest. Dokonuje się dominacja pośrednia, poprzez podsuwanie pewnych zachowań, które ludzie przyjmują"

Niemiecki filozof pisał: „Represja przestaje być dostrzegana w wielkim, obiektywnym porządku rzeczy, który mniej lub bardziej adekwatnie nagradza posłuszne jednostki (...). Konflikt między seksualnością a cywilizacją rozwija się w ramach tego procesu dominacji”' ${ }^{\prime 1}$. Ludzie nie żyją już własnym życiem, ale pełnią (perform) $\mathrm{z}$ góry ustalone funkcje. Pracując nie są w stanie zaspokoić własnych potrzeb i nie wykorzystują własnych uzdolnień, ponieważ pracują w warunkach alienacji. Zasada performansu obejmuje represywną sublimację ludzkich pragnień, gdyż we współczesnym społeczeństwie libido zostaje odwrócone ku użytecznym społecznie zadaniom. Jednostka, wykonując różne czynności, pracuje dla siebie tylko w takim stopniu, w jakim pracuje dla aparatu, oddając się działaniom, które przeważnie nie mają nic wspólnego z jej uzdolnieniami

17 Por. H. Marcuse, Człowiek jednowymiarowy, dz. cyt., 54.

18 P. Duchliński, A. Kobyliński, R. Moń, E. Podrez, dz. cyt., 206.

19 H. Marcuse, Eros i cywilizacja, dz. cyt., 61. 
i pragnieniami ${ }^{20}$. Dla Marcusego kluczowe jest to, że jednostki tolerują performatywną alienację, co więcej, poprzez proces represywnej desublimacji ${ }^{21}$ zaczynają czerpać z niej przyjemność. Co więcej, skutki działania performansu obejmują całe społeczeństwo. Analizując Erosa i cywilizacje zauważamy, że Marcuse nazwał przedmiot swoich badań zasadą wydajności (ang. performance), którą z zasadą performansu utożsamił McKenzie.

W związku z tym diagnoza McKenziego wydaje się słuszna o tyle, o ile utożsamienie zasady wydajności w wydaniu Marcusego z zasadą performansu w wydaniu współczesnym jest właściwe. $Z$ dużą dozą pewności można powiedzieć, że McKenzie ma rację, ale w tym miejscu zatrzymuje się. Zauważył, co prawda, że filozofia Marcusego wpisuje się w obszar performatyki, jednakże nie poszedł dalej. Być może amerykański naukowiec nie ukazał ważności tego aspektu filozofii Marcusego, bowiem nie było to dla niego ważne w rozważaniach na temat performansu. Poczynione spostrzeżenie było mu potrzebne jedynie do odkrycia źródła performansu organizacyjnego, przez co pominął to, że Marcuse dokonał rozróżnienia na zasadę wydajności i zasadę rzeczywistości, a raczej wyłonił zasadę wydajności - performansu - z zasady rzeczywistości.

Co więcej, McKenzie nie zauważa też, że Marcuse idzie o krok dalej niż Freud i w analizach zasady wydajności, odmianie Freudowskiej zasady rzeczywistości, szuka on warunków wstępnych do stworzenia koncepcji nowej, jakościowo różnej zasady rzeczywistości,

20 Por. tamże, 60.

21 Pod pojęciem represywnej desublimacji, której Marcuse dał szeroko wyraz w Człowieku jednowymiarowym rozumiem odwrotność sublimacji, czyli skierowanie pierwotnych popędów (seksualnego, agresji) na inne cele, bardziej wysublimowane, wytworzone przez kulturę, takie jak sztuka, nauka czy sport. Sublimację postrzegam jako rzeczownik od przymiotnika wysublimowany, czyli sublimacją na potrzeby niniejszego artykułu byłoby działanie mające na celu nadanie szlachetności, piękna, kultury, czy jakby chciał tego Marcuse - elementów transcendujących czy opozycyjnych. 
która miałaby zapanować w nowym społeczeństwie. Zagadnienie to wydaje się interesujące i zasługuje na rozwinięcie.

\section{DIAGNOZA CYWILIZACJI OPARTEJ O ZASADĘ WYDAJNOŚCI I PROPOZYCJA NOWEJ ZASADY RZECZYWISTOŚCI}

Przyjrzyjmy się zatem, o co dokładnie chodziło filozofowi ze szkoły frankfurckiej. Podczas gdy McKenzie wiąże performans z zasadą wydajności, Marcuse idzie w innym kierunku. Próbuje on określić, jak można byłoby stworzyć nierepresywną zasadę rzeczywistości, przez co zrywa z poglądami Freuda, który stworzenie nierepresywnej cywilizacji uważał za niemożliwe. Ojciec psychoanalizy ukazywał nieprzezwyciężalny konflikt istniejący między zasadą przyjemności a zasadą rzeczywistości. Marcuse dokonał dwóch rzeczy. Zerwał częściowo z poglądami Freuda i odróżnił zasadę rzeczywistości od zasady wydajności, czy też wyróżnił zasadę wydajności z zasady rzeczywistości i opisał ją. Doszedł do wniosku, że odkrył zasadę rzeczywistości, a zwłaszcza tę jej postać, która rządziła powstaniem i rozwojem cywilizacji zachodniej, czyli właśnie zasadę wydajności, poprzez syntezę perspektywy Freudowskiej i Marksowskiej.

Z filozofii psychoanalitycznej zaczerpnął przekonanie o zniewoleniu człowieka przez kulturę, bo, jak utrzymywał Freud, historia człowieka to historia jego represji. Kultura ogranicza go w wymiarze społecznym i biologicznym, a przede wszystkim jego strukturę popędową. Okazuje się jednak, że ograniczenie takie jest fundamentalnym warunkiem postępu ${ }^{22}$. Gdyby popędom człowieka pozostawić swobodę działania i dążenia do naturalnych celów, kolidowałyby z procesami trwałego budowania i podtrzymywania. Uwydatniłaby się ich skłonność do równoczesnego jednoczenia i niszczenia. Niekontrolowany Eros może równać się z popędem śmierci i być jednakowo zgubny. Destrukcyjna siła popędów jest wynikiem ich dążenia

22 Por. H. Marcuse, Eros i cywilizacja, dz. cyt., 29. 
do zaspokojenia, którego odmawia im kultura. Chodzi o zaspokojenie jako cel sam w sobie, zaspokojenie, które będzie natychmiastowe. Popędy są zatem zmuszone do odchylenia się od celu i do zahamowania w swym dążeniu. Cywilizacja zaczyna się tam, gdzie ma miejsce skuteczne zanegowanie pierwotnego celu popędów, czyli natychmiastowego zaspokojenia potrzeb. Ich umiejscowienie w organizmie człowieka i ich kierunek pozostają takie same, zmieniają się jednak ich cele i przejawy ${ }^{23}$. Człowiek rządzony przez zasadę przyjemności był wiązką zwierzęcych popędów, jednakże w momencie ustanowienia zasady rzeczywistości stał się zorganizowanym ego, podmiotem świadomym i myślącym, jednocześnie przystosowanym do narzuconej mu z zewnątrz przez społeczeństwo racjonalności. Nabywa umiejętności koncentrowania uwagi, zapamiętywania i osądzania, lecz aparat psychiczny skutecznie podlega zasadzie rzeczywistości. Funkcję motorycznego wyładowania, zaspokojenia popędów, dominującą w zasadzie przyjemności, w zasadzie rzeczywistości zastąpiło działanie, przemienianie rzeczywistości, ale przemienianie stosowne. W rezultacie działania rozszerza się obszar pragnień człowieka oraz narzędzia ich zaspokojenia ${ }^{24}$.

Podążając za logiką Marcusego, można by powiedzieć, że konsekwencją świadomego działania człowieka powinno być działanie wolne, a co za tym idzie, zmierzające do usuwania zewnętrznych przeszkód, które utrudniają zaspokojenie przyjemności. Dlaczego zatem tak się nie dzieje? Aby to dobrze zrozumieć, należy zauważyć, iż Marcuse sądził, że wraz z nastaniem zasady rzeczywistości pragnienia człowieka oraz jego dążenie do zmiany rzeczywistości, przestały należeć wyłącznie do niego, ale zaczęły być organizowane przez społeczeństwo, w którym on żyje ${ }^{25}$. Marcuse uznał współczesną cywilizację za rodzaj walki z wolnością, jeśli przez wolność będziemy

\footnotetext{
23 Por. tamże, 29-30.

24 Por. tamże, 31-32.

25 Por. tamże, 32.
} 
rozumieli brak jakiejkolwiek represji. Według Freuda zasada przyjemności zostaje wchłonięta przez zasadę rzeczywistości, która ją represjonuje. Jednakże zasada przyjemności nadal jest częścią zasady rzeczywistości, ciągle się w niej znajduje i mimo tego, że jest to istnienie wyparte, zachowuje całą swoją siłę i potęgę w nieświadomości, z której próbuje się wydobyć. Co więcej, w pewien sposób wpływa na samą zasadę rzeczywistości ${ }^{26}$.

I w tym to aspekcie widać istotną różnicę między Freudem a Marcusem. Freud bowiem uważał, że walka o byt jest wieczna, stąd też uznał zasadę rzeczywistości za antagonistyczną, stojącą w opozycji do zasady przyjemności. W konsekwencji pomysł stworzenia wizji nierepresywnej cywilizacji uznał za niemożliwy do realizacji. Marcuse ma co do tego spore wątpliwości. Zgadza się on z Freudem i jego psychoanalityczną teorią, jednak podważa pogląd o nieprzezwyciężalnym konflikcie istniejącym pomiędzy zasadą przyjemności a zasadą rzeczywistości. Tam, gdzie Freud mówił o niemożliwości zaistnienia nierepresywnej kultury, Marcuse wypowiada się o historycznej możliwości usunięcia represywnych mechanizmów kontroli, zniewalających jednostkę. Mechanizmy te chociaż są narzucone przez tę samą cywilizację, to jednak dzięki jej osiągnięciom zasada wydajności może zostać zniesiona ${ }^{27}$. Marcuse doszedł bowiem do wniosku, że skoro represja, jako wynik zasady rzeczywistości, jest zjawiskiem historycznym, a istota represji, czyli skuteczne podporządkowanie popędów pewnym mechanizmom kontroli, nie jest narzucone przez naturę, ale przez człowieka, to także człowiek może spowodować całkowite usunięcie represji z cywilizacji ${ }^{28}$.

Twierdzeniu Freuda o nieuniknionym konflikcie między zasadą przyjemności i zasadą rzeczywistości, a właściwie między seksualnością i cywilizacją, Marcuse przeciwstawia wizję jednoczącego

\footnotetext{
26 Por. tamże, 33.

27 Por. tamże, 179.

28 Por. tamże,181.
} 
i niosącego zaspokojenie Erosa, który został wyczerpany i skrępowany przez cywilizację. Koncepcja swobodnego Erosa zakłada trwałe i cywilizowane stosunki społeczne, odrzuca natomiast oparte na represji zorganizowane stosunki społeczne, hołdujące zasadzie wydajności ${ }^{29}$. Odrzuca on zatem tezę o antyspołecznym charakterze seksualności, która czyni cywilizację represywną wobec tejże seksualności. Idąc dalej, w opozycji Freudowskiego rozumienia represji, wprowadza on pojęcie nadrepresji, czyli represji niekoniecznej. Marcuse jest przekonany, że współczesna cywilizacja może całkowicie wyzbyć się represji w jej Freudowskim rozumieniu, bowiem rozwój nauki i technologii już stworzył potencjał pozwalający na redukcję dużej części pracy, a co za tym idzie, związanego z pracą przymusu i alienacji.

W Erosie i cywilizacji postawił on interesującą tezę, że człowiek może uniknąć losu, jak to nazywa, Państwa Dobrobytu-Przez-Wojnę. Może się to stać poprzez obranie nowego punktu wyjścia, czyli nabycie przekonania, że możliwe jest zorganizowanie takiego sposobu produkcji, który usunie ubóstwo i konieczność pracy ponad siły, co dotychczas prowadziło do panowania jednych nad drugimi i do wyzysku. Według Freuda, represyjna modyfikacja popędów, będąca wynikiem rządów zasady rzeczywistości, jest podtrzymywana i wzmacniana przez walkę o byt. Niedostatek uczy ludzi, że nie jest możliwe swobodne zaspokojenie popędów, że nie mogą oni żyć w zgodzie z zasadą przyjemności. Społeczeństwo, które narzuca sublimację popędów, kieruje się motywem ekonomicznym, „ponieważ nie posiada dostatecznej ilości środków żywności, by utrzymać swoich członków bez pracy, musi ograniczać liczbę swoich członków i skierować ich energię od czynności seksualnej ku pracy"30. Idąc tropem ojca psychoanalizy, Marcuse wskazuje, że jedynym elementem ludzkiego aparatu psychicznego, wolnym od zasady rzeczywistości, jest fantazja. Jest ona wolna od kulturowych przemian, a tym samym

29 Por. tamże, 58.

30 Tamże, 34. 
wierna zasadzie przyjemności. Odwołuje się przy tym do mitologii, co pomaga mu w tworzeniu utopii, że rozwój cywilizacji może pod odpowiednimi warunkami przywrócić zasadzie przyjemności właściwe jej miejsce ${ }^{31}$.

Aby dobrze zrozumieć koncepcję nowej cywilizacji, przedstawioną przez Marcusego, należy przyjrzeć się jeszcze drugiemu filarowi jego konstrukcji, na którym opiera on swoją wizję, a mianowicie na Marksowskiej teorii sił wytwórczych. Punktem wyjścia dla jego rozważań na ten temat jest zagadnienie alienacji gospodarczej, czyli pracy zniewolonej. Alienacja gospodarcza to zjawisko, które zostało po raz pierwszy zauważone i wyjaśnione przez Marksa, a Marcuse idzie tym samym tokiem rozumowania. Uznał on, że najważniejszą miarą wolności człowieka jest wykonywanie wolnej pracy, czyli takiej, którą sam sobie wybrał, której warunki określił, za której wyniki odpowiada i której owocami może się cieszyć do woli. Zwracając uwagę na tezę Marksa, że praca jest czynnikiem kształtującym człowieka jako takiego i stanowiącym w jego życiu czynnik podstawowy, Marcuse dochodzi do wniosku, że alienacja ludzkiej pracy stanowi zasadniczą formę zniewolenia człowieka. „Pod rządami zasady wydajności ciało i umysł zostają przekształcone w narzędzia wyalienowanej pracy"32. Pracę zniewoloną człowiek podejmuje tylko dlatego, że jest zmuszony koniecznością ekonomiczną. Zostaje on w ten sposób uzależniony ekonomicznie od innego człowieka. Alienacja pracy niszczy dążenie do posiadania własności prywatnej, które jest nieodłączne od natury ludzkiej. Jak wiadomo Marks postulował zniesienie własności prywatnej. Tymczasem Marcuse uważa, że posiadanie własności prywatnej jest warunkiem polepszenia i zmiany kondycji człowieka.

31 Marcuse w swojej filozofii przywołuje postacie zaczerpnięte z mitologii greckiej. Chce w ten sposób zobrazować działanie zasady rzeczywistości, utożsamiając z nią działanie Prometeusza. Zaś symbolami nowej cywilizacji mają być figury Orfeusza i Narcyza, będące archetypami nowego człowieka. Więcej na ten temat czytelnik może przeczytać w Erosie i cywilizacji Marcusego.

32 H. Marcuse, Eros i cywilizacja, dz. cyt., 61. 
Zniesienia własności prywatnej dokonać miałaby klasa zainteresowana zniesieniem wszelkiej alienacji - klasa robotnicza. Dobrobyt jednego człowieka nie może wynikać $\mathrm{z}$ wyzysku drugiego, co zauważa także R. Palacz, komentując poglądy Marksa ${ }^{33}$. Pisze on: „Nie zauważono jednak, że nowy ustrój sam stworzył uprzywilejowane klasy, alienację i prowadził do ubezwłasnowolnienia społeczeństwa. Marks krytykował także socjalizm utopijny za jego błędy, ale nie dostrzegł, że również jego koncepcje, w wielu przypadkach, mają podobny charakter"34.

W oparciu o tezę zniesienia własności prywatnej, zaczęto budować nowe społeczeństwo, a częściowo wizja ta mogła stać się inspiracją dla Marcusego ${ }^{35}$. W myśl filozofii Marksa źródłami rozkładu społeczeństwa kapitalistycznego są jego wewnętrzne mechanizmy ekonomiczno-społeczne oraz procesy prowadzące do alienacji. Alienacja pracy pociąga bowiem za sobą utratę przez człowieka ludzkich wartości. Analizując dzieła Marksa, dostrzegamy, że postulował on konieczność obalenia dotychczasowego kształtu istniejącego społeczeństwa, gdzie ciągle dochodzi do alienacji człowieka. Nietrudno więc dostrzec analogię poglądów Marcusego i Marksa, bowiem ten drugi w rewolucji upatrywał szansę na stworzenie warunków gwarantujących pełny rozwój osobowości ludzkiej ${ }^{36}$. Marks uważał, że potrzeby ludzkie nie są jedynie potrzebami materialnymi i biologicznymi. Odnoszą się one do całości ludzkiego istnienia, do jego istoty. Człowiek jako byt wolny i wszechstronny pragnie samorealizacji, którą może osiągnąć poprzez twórczą pracę i uniwersalną

33 Por. R. Palacz, Klasycy filozofii, Warszawa-Poznań 2005, 224.

34 Tamże, 224.

35 Warto tutaj dodać, że teoria krytyczna, której Marcuse był przedstawicielem, miała za zadanie przezwyciężać braki teorii marksistowskiej poprzez teoretyczny namysł nad złem charakteryzującym społeczeństwo burżuazyjne. Namysł taki stanowił główne osiągnięcie szkoły frankfurckiej a Marcusemu udało się tego dokonać m.in. w postaci dzieła Człowiek jednowymiarowy.

36 Por. R. Palacz, dz. cyt., 222-223. 
aktywnośćc ${ }^{37}$. Uniwersalność zainteresowań i wolność działania miały prowadzić do ustanawiania wszechstronnych i właściwych stosunków jednostki ze światem. Stąd płynęło zainteresowanie Marksa ekonomią, gdyż uważał, że jej znajomość umożliwia realizację celu, jakim jest wyzwolenie człowieka. Jak wiadomo, Marcuse inspirował się filozofią marksistowską i łączył ją z poglądami Freuda. Warto dodać, że w późniejszym okresie swojej twórczości, zarzucał on filozofii marksistowskiej wiele błędów, m.in. zatrzymanie się na tworzeniu utopii. Marcuse uważa, że idea socjalizmu Marksa nie jest jeszcze zdeterminowaną negacją kapitalizmu. Co więcej, należy ona do przestarzałego już etapu rozwoju sił wytwórczych. Postuluje zatem „koniec utopii”: odrzucenie tych teorii i idei, które używają pojęcia utopii, do potępienia warunków historyczno-społecznych, które uznać można za możliwości. Być może Marcuse zdecydował się na krytykę Marksa w momencie, kiedy jego filozofia zaczęła być wprowadzana w życie przez lumpenproletariat, mniejszości rasowe i studentów. Globalna rewolucja Marcusego nabrała tempa rozwoju.

Przyjrzyjmy się teraz pewnym warunkom niezbędnym, jego zdaniem, do stworzenia nowego społeczeństwa i do całkowitego zlikwidowania represji. Marcuse twierdził, że jeśli je wprowadzimy, to stworzymy nierepresywną zasadę rzeczywistości. Korzystając z teorii Freuda, opisuje on szczególowo zasadę rzeczywistości, która rządzi rozwojem cywilizacji zachodniej, czyli zasadę wydajności. Wskazuje na jej główne składowe, tj. dominację i alienację, pochodzące z panującej formy organizacji pracy. One to w znacznym stopniu określają wymagania narzucone przez tę zasadę. Niemiecki filozof stawia zasadne pytanie. Docieka tego, czy utrzymujące się „rządy” zasady wydajności jako zasady rzeczywistości w postaci dominacji i alienacji, obejmującej już nie tylko sferę pracy, należy rozumieć jako rzecz powszednią i, co za tym idzie, spostrzegać działania cywilizacji w świetle tej zasady.

37 Por. H. Marcuse, Człowiek jednowymiarowy, dz. cyt., XIX. 
Koncentrując się na pewnych historycznych prawidłowościach i łącząc je z psychoanalityczną teorią człowieka, dochodzi on do wniosku, że zasada wydajności stwarza warunki wstępne do powstania jakościowo odmiennej, nierepresywnej zasady rzeczywistości. Chodzi mu o to, że rozwój cywilizacji rządzonej przez zasadę wydajności zdołał osiągnąć taki stopień wydajności produkcji, na którym możliwe byłoby znaczne ograniczenie wymagań dotyczących oszczędnego gospodarowania energią popędową i większe przyzwolenie na korzystanie z przyjemności ${ }^{38}$.

Niemniej Marcuse zauważa, że istniejąca forma organizacji pracy i wiążące się z nią zniewolenie popędów nie są teraz uzasadniane tzw. walką o byt, ale chęcią jej przedłużania, czyli interesem dominacji. Stąd też apeluje o nową wrażliwość społeczną. Co więcej, okazuje się, że ta sama filozofia zachodnia, która z myśli oświeceniowej stworzyła koncepcję rozumu umożliwiającą dominację zasady wydajności, doszła ostatecznie teraz do wypracowania wizji wyższej formy rozumu. Na nową koncepcję rozumu składają się takie elementy, jak receptywność, kontemplacja, radowanie się, czyli cechy, które są kluczowe dla Marcusowskiej wizji nowej wrażliwości. Chodzi o to, że postęp technologiczny i naukowy, który ludzie osiągnęli do tej pory, wykorzystywany jest m.in. do konstrukcji broni nuklearnej. Aby zatrzymać ten proceder, Marcuse nawołuje do przemienienia wrażliwości człowieka tak, aby zasoby, którymi dysponuje, używane były w celach przynoszących korzyści całemu społeczeństwu, np. w celu chronienia środowiska. Marcuse jednocześnie neguje istnienie bytu transcendentnego. Nie ma Boga, nie ma Absolutu, nie ma nawet nietzscheańskiego nadczłowieka. Marcuse oczekuje zatem przemiany człowieka w taki sposób, aby odznaczał się nową wrażliwością.

Nowa wrażliwość człowieka ma być wynikiem erotyzacji i estetyzacji stosunków społecznych. Co więcej, ma się przyczynić do większej solidarności między ludźmi. Erotyzacja społeczeństwa 
oznacza nie tylko swobodne relacje erotyczne, ale także erotyzację wszystkich ludzkich czynności, które staną się przyjemnościami, oraz erotyzację wszelkich doznań zmysłowych. Natomiast estetyzacja życia społecznego ma być skupieniem się na pięknie. Przede wszystkim na pięknie natury. Ma być tworzeniem piękna poprzez osąd, wybór i percepcję estetyczną. Percepcja estetyczna jako wyobraźnia - jak wskazuje Marcuse - posiada charakter zmysłowy oraz twórczy. Znaczy to, że w dokonywanej przez siebie samą syntezie tworzy piękno. Okazuje się, że swoboda erotyczna oraz wrażliwość na piękno i naturę ma wzmacniać więzi między ludźmi, przyczyniać się do współodczuwania z nimi i solidaryzowania się.

Wydaje się, że za koncepcją nowej cywilizacji kryją się archetypy zaczerpnięte z mitologii. Chodzi o postaci Orfeusza i Narcyza. Funkcjonują one w wyobraźni, w odróżnieniu od bohaterów represywnej produktywności stworzonych przez kulturę. Archetypy te symbolizują twórczą receptywność i obrazują wizję spełnienia człowieka oraz przyrody, nie poprzez eksploatację i dominację, jak ma to miejsce we współczesnej kulturze, ale przez uwolnienie sił libidalnych. Nierepresyjny porządek staje się możliwy dzięki popędom seksualnym, które w nowych warunkach egzystencjalnych i społecznych stwarzają trwałe stosunki erotyczne pomiędzy dojrzałymi jednostkami. Libido ma zostać uwolnione ${ }^{39}$. Jednakże wizja nierepresywnej cywilizacji, którą Marcuse tworzy na podstawie mitologii i filozofii, ma także na celu stworzenie nowych relacji między rozumem a popędami. Celem jest zjednoczenie Erosa z Logosem. Moralność, będąca wytworem kultury, zostaje, w przekonaniu niemieckiego filozofa, obalona przez stworzenie harmonii między popędową wolnością a porządkiem społecznym. Popędy uwolnione od tyranii zniewalającego rozumu dążą do utrwalenia swobodnych i trwałych stosunków egzystencjalnych, dając tym samym początek nowej zasadzie rzeczywistości ${ }^{40}$. 
W tym miejscu należy zadać pytanie, czy te warunki, które wymienia Marcuse, są wystarczające do powstania nierepresywnej cywilizacji. Nawet jeśli na powyższe pytanie można by odpowiedzieć twierdząco, to pojawiają się kolejne, związane $z$ jego rozumieniem człowieka. Czy niemiecki filozof na pewno dobrze ocenił naturę ludzką? Znamy ją bowiem $\mathrm{z}$ funkcjonowania $\mathrm{w}$ zasadzie rzeczywistości i trudno przewidzieć, jak człowiek mógłby się zachować w nowej rzeczywistości nawet w sprzyjających warunkach, które tak wyraźnie starał się określić Marcuse. Sugeruje on, że nowa zasada rzeczywistości byłaby w pewnym sensie powrotem do zasady przyjemności, tyle że nieco zmienionej. Tutaj można zastanowić się, czy osoby, które nie hołdują zasadzie przyjemności, nie będą się czuły represjonowane. Czy ci, którzy uważają, że zasada przyjemności powinna być regulowana, nie będą czuć się zmarginalizowani.

Częściową odpowiedzią na te pytania może być przedstawienie antropologicznych skutków marksistowskiej filozofii, czy raczej marksistowskiej soteriologii $\mathrm{w}$ zestawieniu $\mathrm{z}$ koncepcją chrześcijańską. Każdy, kto konstruuje normy postępowania, jest przekonany, że pozwolą one uniknąć człowiekowi zagrażającego mu zła. W niektórych systemach etycznych perspektywa wyzwolenia człowieka jest dość wyraźna. Jak zauważają Styczeń i Szostek, do takich systemów należą chrześcijańska i marksistowska doktryna moralna ${ }^{41}$. Wskazują oni, że Chrystus, jak również i Marks, wzywają człowieka do zmiany swojego dotychczasowego położenia. Na tym jednak podobieństwa się kończą, bowiem programy ich różnią się co do koncepcji człowieka oraz istoty niszczącego go zła. Źródłem odmiennych antropologii, oddzielającym oba sposoby myślenia o człowieku, okazuje się rozumienie stosunku człowieka do prawdy o nim samym. Czy człowiek może wyzwolić swoje jestestwo jako człowiek, gdy prawdę o sobie sam sobie wytwarza, czy wówczas, kiedy ją uznaje za taką, jaka

41 Por. T. Styczeń, A. Szostek, Liberalizm po marksistowsku. Antropologiczne implikacje marksistowskiej soteriologii, w: T. Styczeń, Wprowadzenie do etyki, Lublin 1993, 194. 
ona jest i się nią w sposób wolny kieruje? Za charakterystyczne dla liberalizmu uznać można przekonanie o zupełnej wolności, nawet w odniesieniu do prawdy o samym sobie. W imię tej wolności człowiek może - jak zauważają cytowani autorzy - swobodnie kreować siebie, wytwarzać prawdę o sobie samym ${ }^{42}$. Analizując dzieła Marksa dostrzegamy, że jego doktryna stanowi szczególnie dojrzałą formę liberalizmu. Marksizm proponuje człowiekowi uwolnienie go od obiektywnej prawdy o nim samym. A kiedy prawda o nas samych jest zacierana, nie znamy jej źródła oraz pochodzenia działających w nas mechanizmów, rodzi się wówczas w człowieku frustracja, wyzwalająca jeszcze większe dążenie do pozornej wolności.

A zatem nasuwa się jeszcze jedno pytanie. Jak ma się do tego wizja Marcusego? Wydaje się, że w świetle tak rozumianego liberalizmu, nie jest on marksistą, a raczej liberałem. W liberalizmie upatruje racji zniewolenia i represjonowania człowieka, twierdząc, że właśnie kapitalizm i nowoczesny liberalizm tworzą człowieka jednowymiarowym.

Poglądy Marcusego są częściowo słuszne i łatwo znaleźć tego potwierdzenie. Jednakże chce on zmienić naturę ludzką, tworząc ją bardziej estetyczną i postuluje, m.in. nową wrażliwość. Nie zauważa jednak, że ta nowa wrażliwość, o której mówi, zdaje się być produktem liberalizmu. Uwolnienie jednych zniewala drugich. $Z$ jednej strony wielu obywateli łudzi się, że są istotami wyzwolonymi. Pytani o zasadę przyjemności odpowiedzieliby, że dzięki przemianom społecznym została ona w dużej mierze zrównana z zasadą rzeczywistości. Ludzie ci pracują ciężko, jednakże mają wrażenie, że cała ich sfera seksualna znajduje zaspokojenie. A to dlatego, że istnieje przyzwolenie społeczne na jednorazowe, krótkotrwałe kontakty seksualne. $Z$ drugiej strony można by pytać, czy na pewno stosowane performanse, mające zerwać z normami i dostarczyć przyjemności, pozwalają ludziom na rozrywkę kulturalną, na sztukę, na sport. Jak zauważają autorzy cytowanej już książki, stosowane performanse 
koncentrują się obecnie wokól takich problemów jak np. prawa mniejszości narodowych, prawo do aborcji, orientacje seksualne. Twórcy tych performansów walcząc o nowe prawa, o uzyskanie wolności dla jednych, narzucają pozostałym obowiązek, by takie prawa respektowali. Powstaje pytanie, czy da się przy pomocy performansów zerwać z normatywnością. Istnieje co do tego pewna wątpliwość. Mają rację ci, którzy twierdzą, że rzeczywistość jest normatywna. Performatyka jako kwestionowanie dotychczasowych norm przechodzi niepostrzeżenie w nowy paradygmat ${ }^{43}$.

Wiele wskazuje na to, że przywracanie zasady przyjemności poprzez stworzenie nowej zasady rzeczywistości, proponowanej przez Marcusego, dokonuje się często kosztem represjonowania drugiego. „Z jednej strony mówi się o potrzebie zerwania pewnych więzów, religijnych, moralnych, z drugiej trzeba przekroczyć pewien wysoki próg, by znaleźć się w odpowiedniej grupie. Należy poddać się konkretnej normie społecznej lub moralnej, tylko że innej niż dotychczasowe. Skuteczność staje się normą"44. Jak twierdzą autorzy O normatywności wetyce, nie ma sposobu na wyzbycie się normatywności, wpisana jest ona bowiem w ludzką rzeczywistość. Próby jej wyeliminowania kończą się niepowodzeniem, rodzą inny rodzaj normatywności ${ }^{45}$. Warto wziąć to pod uwage przy analizowaniu dzieł Marcusego, który być może nieświadomie, ale w konsekwencji chciał wyzwolić człowieka od prawdy o nim samym. Co więcej, jego filozofia była odpowiedzią na wołanie niezadowolonego społeczeństwa o zmianę istniejących norm.

43 Por. P. Duchliński, A. Kobyliński, R. Moń, E. Podrez, dz. cyt., 196.

44 Tamże, 196-197.

45 Por. tamże, 197. 


\section{WNIOSKI}

Podsumowując, rozwój performatyki zmienił rozumienie normatywności. Częściej mówi się o normach konstruowanych wspólnie, a nie przez kogoś ustanowionych. Łatwo można odnaleźć pewne analogie z koncepcją liberalistycznego kolektywizmu Marksa: niech podmiot zbiorowy, nie indywidualny, kreuje sam siebie ${ }^{46}$. Dotyczy to przede wszystkim zarządzania, gdzie normy są ustalane, uzgadniane są sposoby zarządzania. Podobnie dzieje się we wszystkich dziedzinach życia. Dopiero w trakcie działania człowiek jest w stanie powiedzieć, co jest dla niego najkorzystniejsze. Skuteczność przestaje być celem, staje się nim teraz kreatywność i zróżnicowanie ${ }^{47}$. McKenzie, pisząc o teorii performansu, wskazał, że performans organizacyjny z powodzeniem można utożsamić z Marcusowską zasadą wydajności, a oba uznać za nieludzkie. Można się zastanowić, dlaczego inni komentatorzy Marcusego nie poszli w tym kierunku, dlaczego nie zauważyli analogii pomiędzy zasadą wydajności a performansem organizacyjnym.

Dokonał tego dopiero autor Performuj albo... Jednakże zatrzymał się on na tym odkryciu i nie rozwinął dalej myśli Marcusego, szczególnie tej, która dotyczy jego wizji nowego społeczeństwa, mniej represywnego. U Marcusego pokazane jest jednak, że to, co opisywał, jest represyjne. Co więcej, Marcuse wpłynął na McKenziego, a ten zauważył, że performanse są obecnie dobrze widoczne. Dostrzegamy je dziś w organizacji firm, gdzie performans stosuje się w pełni, gdzie jeden człowiek wciąż ocenia drugiego, nieustannie czegoś od niego wymaga.

Proponowana przez Marcusego wizja nowego społeczeństwa częściowo się ziściła. W jego koncepcji zasada przyjemności została dowartościowana, widać to dobrze na przykładzie chociażby

46 Por. T. Styczeń, A. Szostek, dz. cyt., 204.

47 Por. P. Duchliński, A. Kobyliński, R. Moń, E. Podrez, dz. cyt., 201. 
swobodnego życia seksualnego podejmowanego przez wielu ludzi. Jednakże z drugiej strony zasada przyjemności nie zdominowała do końca zasady rzeczywistości. Ta nadal rządzi w postaci zasady dominacji i wydajności wpływając na działania i zachowania praktycznie każdego człowieka. Pod pozorem twórczości i innowacyjności stosuje się nieludzkie praktyki w postaci performansu organizacyjnego. Człowiek myśli, że żyje i działa, kierując się zasadą przyjemności, że jego kreacje, twórczość, osiągnięcia i pomysły uczynią go szczęśliwym $i$ atrakcyjnym. Na tym polega trafność diagnozy Marcusego, a jednocześnie jej fałszywość, gdy twierdzi on, że współczesnej jednostce może udać się uzgodnienie zasady przyjemności z zasadą wydajności. Obserwacja życia i pracy ludzi dzisiaj unaocznia nam, że tak naprawdę jednostka funkcjonuje hołdując zasadzie rzeczywistości, pracując ponad siły. Autorzy $O$ normatywności w etyce wskazują, że siły mutacyjne ciągle przechodzą w inne siły normatywne. Stwarzają one nowy rodzaj normatywności, najczęściej bardziej represyjnej. Performanse wciąż dążą do zniesienia dotychczasowych norm. Stawiając na kreatywność i nieprzewidywalność, performerzy twierdzą, że życia nie da się zamknąć w żadnych schematach i że trzeba czynić je coraz bogatszym ${ }^{48}$. Nieskuteczność próby zniesienia dotychczasowych norm najwyraźniej widać $\mathrm{w}$ dziedzinie organizacji pracy oraz produkcji. „Dążenie do zerwania z jakimikolwiek normami prowadzi do stworzenia nowych, bowiem wszelkie formy sprzeciwu i buntu stają się nowymi uregulowaniami normatywnymi (...). W performatyce chodzi o to, aby podejmowane działania były jak najbardziej skuteczne, by można było osiągać jak najlepsze rezultaty jak najmniejszym kosztem"49.

Co więcej, performans mający za zadanie zburzenie dotychczasowego porządku, nie jest w stanie rozwiązać problematyki wolności i zniewolenia. Ucieczka przed mediami elektronicznymi na

48 Por. tamże, 193-194.

49 Tamże, 195. 
dobrą sprawę nie istnieje. Działania podejmowane za pośrednictwem kontrkultury nie wystarczają do tego, by z normatywnością zerwać. Kontestacja normatywności i wszelkiej opresji objawia bowiem swoje represyjne oblicze ${ }^{50}$.

Wydaje się, że diagnoza postawiona we wstępie jest słuszna. Przeprowadzone badania pokazały, że Marcusemu udało się dobrze zdiagnozować, że wprowadzane performanse organizacyjne są li tylko odmianą zasady wydajności. Poszukując sposobu uwolnienia zasady przyjemności, zaproponował pewien model przekształcania rzeczywistości, bo wierzył, że nie ma nieusuwalnego konfliktu między zasadą przyjemności a zasadą rzeczywistości, o ile pojawi się nowa wrażliwość społeczna, jak ją nazywał. Jednakże nie wziął on pod uwagę tego, że siły mutacyjne przechodzą w siły normatywne. Współczesny performans organizacyjny stał się odpowiednikiem zasady wydajności, tyle że w zmienionej formie. Nie zawsze mniej represyjnej. Pozostaje zatem pytanie, czy zmiana zasady rzeczywistości w nową zasadę rzeczywistości, nie jest tworzeniem innej, nie mniej represyjnej normatywności.

BIBLIOGRAFIA

Buck-Morss S., The Origin of Negative Dialectic. Theodor W. Adorno, Walter Benjamin and the Frankfurt-Institute, Hassocks 1978.

Duchliński P., Kobyliński A., Moń R., Podrez E., O normatywności w etyce, WAM - Ignatianum, Kraków 2015.

Held D., Introduction to Critical Theory, Lo 1980.

Jay M., The Dialectical Imagination. A History of Frankfurt School and the Institute of Social Research. 1923-1950, Lo 1973.

Marcuse H., Człowiek jednowymiarowy, tłum. z ang. A. Chwieśko, M. Ćwirko-Godycki, Z. Koenig, S. Konopacki, M. Kozłowski, W. Gromczyński, Państwowe Wydawnictwo Naukowe, Warszawa 1991.

Marcuse H., Eros i cywilizacja, tłum. z ang. H. Jankowska, A. Pawelski, Wyd. Muza, Warszawa 1998.

50 Por. tamże, 199. 
McKenzie J., Performuj albo... Od dyscypliny do performansu, tłum. z ang. T. Kubikowski, Wyd. Universitas, Kraków 2011.

Nietzsche F., Niewczesne rozważania, tłum. z niem. M. Łukasiewicz, Wyd. Znak, Kraków 1996.

Palacz R., Klasycy filozofii, Polskie Wydawnictwo Prawnicze Iuris, Warszawa-Poznań 2005.

Styczeń T., Szostek A., Liberalizm po marksistowsku. Antropologiczne implikacje marksistowskiej soteriologii, w: T. Styczeń, Wprowadzenie do etyki, Wyd. Towarzystwa Naukowego KUL, Lublin 1993, 194-212.

Szahaj A., Teoria krytyczna szkoty frankfurckiej, Warszawa 2008.

\section{THE LEGITIMACY OF THE NEW CIVILIZATION CONCEPT PROPOSED BY HERBERT MARCUSE}

Abstract. This article concerns the legitimacy of the diagnosis of McKenzie that Marcuse's philosophy speaks of what today is called organizational performance. But the main purpose of these considerations is to answer the question of whether the proposal to create a new civilization presented by Marcuse and the theoretical attempt to reconcile the pleasure principle with the reality principle is possible. Marcuse wanted to create the vision of a new society as an alternative to the existing industrial society. To this end, he combined Marx and Freud's perspective because he considered that only the combination of theory of the productive forces and psychoanalytical considerations would help determine the necessary conditions for the emergence of a new, non-repressive reality. Marcuse called for the project of a new principle of reality which would also include the pleasure principle. It seems, however, he did not notice that mutation forces pass into normative forces. What Marcuse expected, on one hand, has been fulfilled, on the other, however, created a lot of disadvantages which he did not foresee.

Keywords: organizational performance, performance principle, reality principle, new sensibility, repression, Eros, normativity

\footnotetext{
ALEKSANDRA KLEŚTA

a.klesta@uksw.edu.pl

Uniwersytet Kardynała Stefana Wyszyńskiego w Warszawie, Instytut Filozofii

Wóycickiego 1/3, 01-938 Warszawa

DOI 10.21697/spch.2016.52.1.02
} 